\title{
Producing and using the Historical Relation of Ceylon: Robert Knox, the East India Company and the Royal Society
}

\author{
ANNA WINTERBOTTOM*
}

\begin{abstract}
Robert Knox's An Historical Relation of the Island of Ceylon was produced, published and enlarged through the collaboration of the author with scholars including Robert Hooke and financial support from members of the East India Company. The Relation should be seen in the context of a number of texts collected, translated or commissioned by the East India Company in cooperation with the Royal Society during the late seventeenth century that informed and shaped both European expansion and natural philosophy. As well as circulating between European intellectual centres, often reorientated in the process of translation, these texts served as practical guides across settlements and trading posts abroad. Comparing written accounts with experience led to annotations and borrowings that served as the basis for further writings. Company records and Knox's own unpublished works reveal how the Relation was used as the basis for bio-prospecting for naturally occurring drugs and food sources and in efforts at agricultural transplantation spanning the Indian and Atlantic Oceans. Through the reports of seamen like Knox, such experiments contributed to contemporary theories concerning the effects of latitude on plant life.
\end{abstract}

In mid-1680 Captain Robert Knox arrived in London after almost twenty years spent in Ceylon (Sri Lanka), an experience which he began to record during his long voyage home as a passenger. ${ }^{1}$ The first person to greet the bearded and whiskered traveller was a 'drugster', a pedlar of the exotic remedies becoming ever more popular in late seventeenth-century London. ${ }^{2}$ The drugster had boarded the ship as soon as it

\footnotetext{
" Ph.D. candidate, CELL Arts Research Centre, Queen Mary University of London and Royal Society. Email: a.e.winterbottom@qmul.ac.uk.

I would like to thank Dr M. C. M. Iqbal of the Institute of Fundamental Studies, Kandy, Sri Lanka, for invaluable discussions and especially for the identification of the several plants by himself and Dr D. S. A. Wijesundera, director general, Royal Botanic Gardens, Peradeniya, Sri Lanka. I am also grateful to Olivia Smith for information about Locke's use of Knox's Relation and to Dr William Poole for bringing the Dutch translation to my attention.

1 R. Knox, An Historical Relation of the Island Ceylon, London, 1681, Chapters 9-13. The account Knox and his fellow captive Steven Rutland gave to the Dutch in Batavia on his arrival with Ryckloff van Goens Junior is translated in F. H. de Vos, 'Extracts relating to Ceylon from the Dag-Register, Batavia, AD. 1678-1680', Journal of the Ceylon Branch of the Royal Asiatic Society (1918), 16, 181-98.

2 Bodleian MS Rawl Q. c. 15, f. 1 (page 527 of the second volume of the Paulusz edition - see below in this note). The autobiography was first printed in An Historical Relation of Ceylon together With somewhat concerning Severall Remarkable passages of my life that hath hapned since my Deliverance out of my captivity (ed. J. Ryan), Glasgow, 1911, and reprinted in R. Knox, An Historical Relation of Ceylon, Revised, Enlarged \& Brought to the verge of Publication as The Second Edition (ed. J. H. O. Paulusz), 2 vols., Dehiwala, 1989. Hereafter referred to as Autobiography with folio numbers and page numbers of the second
} 
docked, eager to buy produce and recipes from its passengers and crew. By chance, he recognized Knox and reunited him with his brother-in-law and sister. Knox would soon meet several others interested in the knowledge he had brought from Ceylon. He was called into the East India Company's Court of Directors to give an account of his travels. ${ }^{3}$ There he was taken aside by Jeremy Sambrooke, a member of the Royal Society. ${ }^{4}$ Through either Sambrooke or his own brother James, Knox was introduced to the polymath Robert Hooke. ${ }^{5}$ By the following year these new contacts and his cousin, the minister and historian Robert Strype, had helped him compose his notes into $A n$ Historical Relation of the Island of Ceylon. The book was printed by the Royal Society's printer Richard Chiswell in August 1681 and financed by subscribers from the East India Company. It became hugely popular during the author's lifetime and has remained a standard source for the island's history ever since.

Recent scholarship has examined the connections between travel narratives and European expansion and the contribution of both to emerging natural philosophy. ${ }^{6}$ This paper explores these issues by studying how the Royal Society and the East India Company were involved in the production of the Relation and how the text was used by both institutions. The methodizing of travel through the interactions of scholars, merchants, sailors, local informants and colonial and creole officials has been traced from

volume of Paulusz's edition in brackets. Knox says that the drugster recognized him as someone who had been abroad for a long time from his old-fashioned beard and whiskers. For the growth in demand for drugs from the East and West Indies during the seventeenth century see P. Chakrabarti, 'Medical marketplaces beyond the West: bazaar medicine, trade and the English establishment in eighteenth-century India', in Medicine and the market in England and Its Colonies, c.1450-c.1850 (ed. M. S. R. Jenner and P. Wallis), Basingstoke, 2007.

3 On 15 September 1680 Knox and Rutland were directed to attend the Committee for Shipping 'to communicate what they had observed of affaires in those parts'. Cf. H. Yule, Diary of William Hedges, 3 vols., London, 1888, ii, p. ccclii.

4 Autobiography, op. cit. (2), 3 (528).

5 Hooke was known to Knox's brother James, from whom he learnt of the escape of Robert Knox. Hooke's diary entry on 12 September 1680 reads. 'Knox his brother escaped out of Ceylon after 22 years detainder'. R. Hooke, The Diary of Robert Hooke, M.A., M.D., F.R.S., 1672-1680 (ed. H. W. Robinson and W. Adams), London, 1935.

6 Since E. Said, Orientalism, New York, 1979, travel accounts have been discussed in a number of contexts. While some have followed his interpretation that European travel accounts tend to perpetuate imperialistic images of the 'other' (for example K. Telsher, India Inscribed: European and British Writing, Delhi, 1995; R. Inden, 'Orientalist constructions of India', Modern Asian Studies (1986), 20, 401-46), others have taken a middle ground (J.-P. Rubiés, Travel and Ethnography in the Renaissance, Cambridge, 2000; J. Carrillo, 'From Mt Ventoux to Mt Masaya: the rise and fall of subjectivity in early modern travel narratives', in Voyages and Visions: Towards a Cultural History of Travel (ed. J. Elsner and J.-P. Rubiés), London, 1999, 57-73) or challenged the genre by extending the frame of reference outside Europe (M. Alam and S. Subrahmanyam, Indo-Persian Travels in the Age of Discovery, Cambridge, 2007, 351-5). Works that have focused on the practical use of travel narratives in the collection of botanical information and species include K. Raj, Circulation and the Construction of Knowledge in South Asia and Europe, 1650-1900, New York, 2007; H. Cook, Matters of Exchange, London, 2007; C. Mukerji, 'Dominion, demonstration and domination: religious doctrine, territorial politics and French plant collection', in Colonial Botany: Science, Commerce and Politics in the Early Modern World (ed. L. Schiebinger and C. Swan), Philadelphia, 2005, 19-33. 
the Iberian world into the writings of the later Renaissance of northern Europe. ${ }^{7}$ Following on from the writings of men like Bacon and Hartlib, the Royal Society, from its inception in the early 1660s, was involved in producing instructions for travellers and guidelines for the authors and compilers of natural histories. ${ }^{8}$ The East India Company's use, as an information source and thus as a source of power, of writings such as travel narratives and directed enquiries has also begun to be explored. ${ }^{9}$ It is argued here that the production of Knox's Historical Relation should be seen as part of an ongoing collaboration between the East India Company and the Royal Society to lay claim to the wealth promised by knowledge of the East by producing travel accounts making use of such guidelines.

Bacon's essay 'On travel' advises that the traveller should carry with him 'some card or book describing the country where he travelleth; which will be a good key to his inquiry' ${ }^{10}$ This highlights a point which seems rather obvious, but which has been somewhat overlooked in many of the recent discussions of travel literature: travel accounts were not intended primarily for the entertainment and information of European elites, but were designed to be carried on journeys. Travellers used them as starting points for their own impressions and scribbled comparisons or corrections in the margins. Several of the books produced in the milieu of the East India Company in this period explicitly state that merchants and factors were their primary audience. For example, Everard's translation of Tavernier's voyages, Samuel Baron's description of Tonqueen (Vietnam) and Thomas Bowrey's Malay dictionary were all intended for use on voyages. ${ }^{11}$

Robert Knox's work provides an especially interesting example of this process of comparison and annotation, because he took an interleaved copy of his own work with him on his later journeys, using the extra pages, as well as unpublished journals, to draw comparisons between his knowledge of Ceylon and his later observations. Knox

7 J. Cañizares-Esguerra, Nature, Empire, and Nation: Explorations of the History of Science in the Iberian World, Stanford, 2006; J.-P. Rubiés, 'Instructions for travellers: teaching the eye to see', History and Anthropology (1996), 9, 2-3, 139-90. See also J. Stagl, A History of Curiosity: The Theory of Travel 1500-1800, Chur, 1995, Chapter 1, esp. 78-81, for the sixteenth-century methodizing of travel narratives within Europe.

8 M. Hunter, 'Robert Boyle and the early Royal Society: a reciprocal exchange in the making of Baconian science', BJHS (2007), 40, 1-23; D. Carey, 'Compiling nature's history: travellers and travel narratives in the early Royal Society', Annals of Science (1997), 54, 23-50; R. Iliffe, 'Foreign bodies, part one: English natural philosophers in Europe', Canadian Journal of History (1998), 52, 467-90; H. Cook and D. Lux, 'Closed circles or open networks: communicating at a distance during the scientific revolution', History of Science (1998), 36, 179-211. For the issues of trust raised by the false account of Formosa by 'George Psalmanazar' see Stagl, op. cit. (7), Chapter 5.

9 H. A. Innes, Empire and Communication, Victoria, 1950; C. A. Bayly, Empire and Information, Cambridge, 1996; M. Ogborn, Indian Ink, Chicago and London, 2007.

10 F. Bacon 'On Travel', in idem, The Essays or Counsels Civil and Moral (1625) (ed. M. Kiernan), Oxford, 1985, 41-2.

11 E. Everard, dedication to Robert Clayton, in J. P. Tavernier, Collection of Several Relations and Treatises Singular \& Curious of Jean Bapista Tavernier Baron of Aubonne Not Printed Among his first Six Voyages, published by E. Everard, London, 1681; British Library (hereafter BL) Sloane MS 1039, f. 133r (for Baron); BL African and Asian Studies MS 763 (Mss Eur. E. 192. 31), ff. 2 (undated but c.1701 or 1702) (for Bowrey). 
has previously been studied almost exclusively in relation to his work on Ceylon, and while it is undeniable that the period of his captivity would have been formative of his ideas about the world at large, the scope of his travel was far wider. Here I explore how the comparisons Knox made between his own description of Ceylon and his observations on later voyages were used by the East India Company in its search for new settlements capable of producing coveted Asians crops for food, medicine, dyes, or cloths. The process of observation was guided at every stage by Knox's ongoing relationship with the Royal Society.

\section{Robert Knox's career}

Robert Knox had been captured in Ceylon, along with his father and other members of crew of the East India Company ship Anne, in 1660 and remained in the central kingdom of Kandy for nineteen years. ${ }^{12}$ He became fluent in Sinhalese and well acquainted with local ways of life through his employments as farmer, moneylender and pedlar. Despite never entering the employment of the king, Knox was evidently well informed about events at the court of Rajasingha II (r. 1634-86). Knox began to compose the Relation on his return journey to England in 1680 after his escape via the Dutch fort at Arippu. ${ }^{13}$

The Relation contains a detailed description of the geography, politics, wildlife, agriculture, religion, languages, laws, learning, medicine and domestic lives of the inhabitants of Kandy, as well as an account of the author's own capture and way of life and the circumstances of other Europeans in the kingdom. It quickly became very popular and was soon translated into German, Dutch and French. ${ }^{14}$ The Relation is said to have formed the basis for Daniel Defoe's hero in both Robinson Crusoe (1719) and Captain Singleton (1720). Knox's contemporary John Locke also drew on the work in his Second Treatise of Government (c.1689). ${ }^{15}$ Along with the Dutchman Philip Baldaeus's description of the Tamil north of the island, published in 1672, and the

12 Kandy emerged as an independent kingdom in the late fifteenth century and remained under indigenous rule until finally falling to the British in 1815. See K. M. de Silva, History of Sri Lanka, London, 1990; and C. Wickremesekera, Kandy at War: Indigenous Military Resistance to European Expansion in Sri Lanka 1594-1818, New Delhi, 2004.

13 Knox's time in Kandy and the political background of the period are discussed in more detail in Knox, Historical Relation (ed. Paulusz), op. cit. (2), i; and in M. C. M. Iqbal, I. Raheem and K. Tennakone, 'The Royal Society, Robert Hooke and a captive from Ceylon: fascinating facets from the 17th century', Notes and Records of the Royal Society of London (forthcoming, 2009).

14 The French versions were published by Paul Marret in Paris (1684) and Amsterdam (1693) and the German text appeared in Leipzig in 1689. The Dutch version by S. de Vries, 't Eyland Ceylon, in sijn binnenste, of 't Koningrijck Candy, Utrecht, 1692, was based on the German version. See Bibliotheque Universalle et Historique, Amsterdam, 1692, 219-44, for a review of the Dutch edition. S. D. Saparamadu, 'Introduction to an historical relation of Ceylon', Ceylon Historical Journal (1958), 5, pp. vii-lv notes that the illustrations in all of these accounts differ, being based on a combination of various illustrations in the original and the artists' imagination.

15 Locke refers to the 'late relation of Ceylon' in his discussion of the effects of absolute monarchy on civil society (Second Treatise of Government, 7, 92). He purchased a copy of Knox's Relation soon after its publication in August 1681. P. Laslett, 'The English Revolution and Locke's "Two Treatises of Government"', Cambridge Historical Journal (1956), 12, 48-9. 
Portuguese captain João Ribeiro's description, which also focuses on the Sinhalesespeaking part of the island, Knox's account continues to form the basis for accounts of the island in the mid-seventeenth century. The work has also been studied for its literary style, its description of the caste system and religion of Ceylon, the Sinhalese vocabulary that it incorporates and, most recently, the natural history it contains. ${ }^{\mathbf{1 6}}$

Knox also left several other manuscripts, which, added to the records of the East India Company and the Royal Society, allow the reconstruction of a fairly comprehensive picture of his life after leaving Ceylon. ${ }^{17}$ Those found so far are his autobiography; the interleaved copy of the Relation, containing significant additions to the original manuscript and intended for publication as a second edition; several letters to his cousin John Strype and one to Lady Worcester, the daughter of the East India Company's governor, Sir Josiah Child; a truncated account of his voyage to Tonqueen in 1681; and his will. ${ }^{18}$ References to Knox appear in the Journal Books and Council Books of the Royal Society and in the Court Books, Letter Books, Original Correspondence and Factory Records of the East India Company, as well as in the diary of Robert Hooke. ${ }^{19}$

In January 1681 Hooke recorded the first of several meetings with Knox, who was accompanied this time by his cousin James Bonnell. ${ }^{20}$ Around the same time Hooke showed the Royal Society a leaf of the talipat palm that Knox had brought back from

16 H. White, 'Knox in its literary aspect', Ceylon Branch of the Royal Asiatic Society (1893), 13, 23-35; and B. Yothers, 'Global captivities: Robert Knox's: An Historical Relation of Ceylon and the New England captivity narrative tradition', Journeys (2007), 8, 1-2; for the caste system see C. R. Boxer, 'Ceylon through Puritan eyes: Robert Knox in the Kingdom of Kandy 1660-1679', History Today (1954), 4, 660-7; for vocabulary see D. W. Ferguson, 'Knox's Sinhalese vocabulary', Ceylon Branch of the Royal Asiatic Society (1896), 14, 155-200, which also includes the Sinhalese words listed by Hooke in BL MS Sloane 1039; and R. Boyle, Knox's Words. A study of the words of Sri Lankan Origin or Association First Used in English Literature by Robert Knox and Recorded in the Oxford English Dictionary, Colombo 2004; for natural history see Iqbal, Raheem and Tennakone, op. cit. (13).

17 The most comprehensive attempt at biography was made by D. W. Ferguson, Captain Robert Knox ... Contributions towards a Biography, Columbo and Croydon, 1896-7, before the discovery of Knox's autobiography or the interleaved copy of the Relation. See also H. A. I. Goonetileke, 'Robert Knox in the Kandyan Kingdom, 1660-1679: a bio-bibliographical commentary', Sri Lankan Journal of the Humanities (1975), 1, 81-151; I. B. Watson, 'Knox, Robert (1641-1720)', ODNB, Oxford, 2004.

18 Autobiography, op. cit. (2); for the correspondence with Strype see Cambridge University Library MSS Add. 1 and Add. 9; for the letter to Lady Worcester see BL MS Sloane. 4067, f. 6; for the Tonqueen journey see BL MS Lansdowne 1197. Knox's will, dated 30 November 1711, is published in Historical Relation (ed. Ryan), op. cit. (2) and Ferguson, op. cit. (17), 55. According to a letter to his cousin Strype, the interleaved book was given to Knox by Richard Chiswell before the first voyage he made after returning from Ceylon and later returned to him for a final check before its intended publication as a second edition (Ferguson, op. cit. (17), 53). The interleaved version with its marginal notes is kept in the British Museum's Centre for Anthropology (M10836) and was published in Knox, Historical Relation (ed. Paulusz), op. cit. (2), ii. Hereafter referred to as Relation (interleaved) with folio numbers and the page numbers of Knox, Historical Relation (ed. Paulusz), op. cit. (2), ii, in brackets.

19 The sections of the diary in which Knox is mentioned directly occur in the Guildhall manuscript recently transcribed and published by F. Henderson, 'Unpublished material from the memorandum book of Robert Hooke, Guildhall Library, MS 1758', Notes and Records of the Royal Society of London (2007), 61, 129-75, and in BL MS Sloane 4024.

20 Henderson, op. cit. (19), 144. 
Ceylon. ${ }^{21}$ In August the same year, Hooke noted that he had given Knox 'queries for ye Indies'. ${ }^{22}$ During this period Knox was presented with the interleaved copy of the Relation. ${ }^{23}$ Knox carried these documents with him when he departed the following month on the Tonqueen Merchant to Tonqueen via the Cape Verde archipelago off West Africa. ${ }^{24} \mathrm{He}$ reached Bantam and Batavia, and returned via Batavia in early $1682 .{ }^{25}$ In November 1683 the Royal Society's council voted to give Knox a present in return for a long list of items that he had given to its repository. ${ }^{26}$ As well as collecting these items during his second voyage, Knox also made and recorded observations relating to difference in tide times in the northern and southern hemispheres. ${ }^{27}$

On 22 September 1683 Hooke provided Knox with 'a picture box, an azimuth perspective [and] a longitude clock' to make further observations on the Royal Society's behalf. ${ }^{28}$ A few months later, Knox sailed in the Tonqueen Merchant, which had since been lengthened, to Madagascar, where he acquired a cargo of slaves for St Helena. He was then intended to go to Timor to procure wood. ${ }^{29}$ But in May 1685, while at St Helena, Knox's crew seized the boat and returned with it to England. Knox followed as a passenger and sued some of the mutineers. In March 1686 Knox was commissioned to take part in the East India Company's war against the Mughal emperor Aurangzeb in Bengal. ${ }^{30} \mathrm{He}$ seems then to have traded independently on the Malabar coast and probably returned to Ceylon before going via the Cape and St Helena to Barbados in 1688, where he repaired his ship before returning to England. ${ }^{31}$

21 The word 'talipat' or 'talipot' refers to the leaves of the fan-palm Corypha umbraculifera. See H. Yule, Hobson-Jobson: A Glossary of Colloquial Anglo-Indian Words and Phrases, and of Kindred Terms, Etymological, Historical, Geographical and Discursive, new edn (ed. W. Crooke), London, 1903, 892. The tree is described and depicted in Knox, op. cit. (1), 15. See also T. Birch, The History of the Royal Society, 4 vols., London, 1756-7, iv, 64 (meeting of 12 January 1681). Hooke mentions the leaf again in his diary of 1682: Henderson, op. cit. (19), 153 (18 May 1682); and Relation (interleaved), op. cit. (18), Part II, Chapter 5 (166). The talipat leaf was again produced in a Royal Society meeting in 1694: Royal Society Journal Book (hereafter JB), x, 6 June 1694.

$22 \mathrm{JB}, \mathrm{x}, 150$, Tuesday 16 August 1681.

23 Knox, Historical Relation (ed. Paulusz), op. cit. (2), ii, p. xv.

24 BL MS Lansdowne 1197.

25 Autobiography, op. cit. (2), 4-6 (530-3).

26 Royal Society, Minutes of Council, ii, 24 November 1683. The objects were presented on 3 November 1683 and included a plough, pictures and medicinal herbs (Birch, op. cit. (21), iv, 226).

2723 April 1684; cf. Ferguson, op. cit. (17). Hooke refers to it being in the hands of the Earl of Clarendon. The journal has not yet been identified.

28 BL MS Sloane, 1039 f. 156.

29 Autobiography, op. cit. (2), 8-24 (535-52); BL India Office Records (hereafter IOR), E/3/90, ff. 170-83. St Helena Archives (hereafter SHA) Consultation Books (hereafter CB), ii, ff. 164-5; Knox is recorded as attending a council meeting of 7 April 1685.

30 Autobiography, op. cit. (2), 31-2 (559-61); and BL IOR E/3/91, f. 47r-48 (or 96-7), 20 March 1685/6.

31 Autobiography, op. cit. (2), 32 (561). There is little information about either journey to Barbados. Presumably Knox was trading slaves on this voyage. He claims on $\mathrm{f} .48$ that the second voyage was 'by order'. Paulusz (in Knox, Historical Relation (ed. Paulusz), op. cit. (2), i, 425-6) transcribes a section from the Dutch records which note his arrival on 3 October 1688, an account he had given them of chasing an English pirate ship to Mascarenhas (Bourbon, Reunion Island) two years previously, and his departure on 13 October. SHA CB, iii, f. 55 (69), notes that Knox left St Helena on 31 October 1688. A later passage mentions that Knox left behind five Portuguese men, whom, according to a letter to Strype dated 1 July 1689 (cf. Ferguson, (17), 42), he had picked up from Mascharinas (Reunion), where they had been shipwrecked. A letter from Josiah Child to 
During 1690 Knox is recorded in Hooke's diary as presenting him with exotic plants and seeds of various types, including cannabis and wood from the Mascarene islands of Mauritius and Rodrigues ('Diego Rois'). ${ }^{32}$ In January 1691, bearing a commission to fight any French ships he encountered, Knox returned via Tenerife to Madagascar, where he remained until September to procure slaves for Bencoulen (Bengkulu, on the west coast of Sumatra). ${ }^{33}$ After arriving from Bencoulen to Fort St George (Madras, now Chennai) via Tranquebar, he was swiftly dispatched to Bengal to trade in cloth, reaching Calcutta (now Kolkata) and staying there until February 1693. After leaving, he returned to St Helena and then to Barbados, losing several men to illness, before returning to England, where he arrived in December $1693 .{ }^{34}$ Although there are no records of Knox carrying out any specific instructions on this voyage, his discussions of natural history with Hooke apparently continued after his return, since he is mentioned as an informant in the Royal Society's records. ${ }^{35}$ After falling out with Sir Josiah Child and refusing several employments with the East India Company, Knox accepted an offer from Samuel Sheppard to go as a free merchant or 'interloper' in his ship the Mary. Leaving in May 1698 for Cadiz, he acquired silver for Surat, where he arrived in February 1699 after calling at St Augustine and trading in Ceylon and on the Malabar coast for pepper.$^{36}$ Knox returned to England in 1701, where he remained until the end of his life.$^{37} \mathrm{He}$ attended two further meetings of the Royal Society to present a number of items from Persia and the Malay world. ${ }^{38}$

\section{Producing the Relation}

Knox states in his dedication to the company that 'I have writ nothing but either what I am assured of by my own personal knowledge to be true ... or what I am assured of by the inhabitants' ${ }^{39}$ This statement, the portrait of Knox that accompanies the text, and the framing story of his captivity, escape and composition of the text on the homeward journey all create the notion of the text as the product of one man's direct experience, a theme taken up by Defoe. As in his autobiography, Knox's Relation does have personal elements. In both texts the author describes his survival of a series of perilous voyages

Governor Blackmore of St Helena dated 20 March 1689 says that he believes Knox is lost (cf. H. F. Janisch, Extracts from the St Helena Records, Jamestown, 1885, online version at http://www.bweaver.nom.sh/ janisch/janisch_1686-99.html; accessed 11 June 2008).

32 BL MS Sloane 4024.

33 Autobiography, op. cit. (2), 34-43 (563-72); also Ferguson, op. cit. (17), 43-5.

34 Autobiography, op. cit. (2), 43-4 (572-3). Knox notes that none were sick until 'my men were taken away to serve in one of the King's ships, whare they got the infection \& brought it one board with them into my Ship that out of 38 men which I brought into this rode I had remaining but 25 to saile the Ship for Eng ... 3 of which ware Indians'. On page 59 (590) Knox describes two of the sailors as slaves. See also Ferguson, op. cit. (17), 46. Yule, op. cit. (3), p. cccliii, notes that Knox appeared at the court in January 1694 and informed the directors of the death of Job Charnock.

35 JB, x, f. 16, 24 February 1697, 15 December 1697 and 4 December 1700.

36 Autobiography, op. cit. (2), 60c-62 (592-5).

37 Autobiography, op. cit. (2), 70 (603).

38 JB, x, f. 19, 7 April 1703, f. 24, 9 June 1703 and f. 124, 12 November 1707.

39 Knox, dedication, in Knox, Historical Relation (ed. Paulusz), op. cit. (2), ii, p. ii. 
and captivities with the intention of demonstrating the workings of Providence. ${ }^{40}$ Nevertheless, the Relation is also a composite work. It was produced, illustrated, financed and finally enlarged through the collaboration of the East India Company and various scholars. It is therefore essential to consider the interests of these entities in producing the book before examining how they used the published work.

In his Autobiography, Knox recognizes the involvement in the Relation of his cousin, John Strype, who 'Composed it into heads \& Chapters, for my papers were very promiscuous and out of forme', and assisted him in adding 'severall inlargements [on] such heads as I had but touched briefly'. ${ }^{11}$ The extent of Hooke's direct involvement with the content or structure of the original Relation is uncertain. ${ }^{42}$ However, his preface suggests that he had significant editorial input in the 'natural history' section of the work. ${ }^{43}$

The illustrations to the Relation are another element in which contributions from someone other than the author seem certain, since Knox's surviving sketch does not provide enough detail for the depictions of costumes and equipment that accompany the final work. ${ }^{44}$ The majority of the illustrations seem to have been composed from a combination of other sources and with reference to objects like the talipat leaf that Knox had brought back with him from Ceylon. ${ }^{45}$ One illustration in which the source of the borrowing is clear is the outline of Knox's map of Ceylon, certainly lifted from Baldaeus's 1672 work Malabar en Coromandel. ${ }^{46}$ Baldaeus's work was published by Johannes Janssonius van Waasberge, whose plates Moses Pitt had acquired as part of the English Atlas project. ${ }^{47}$ This suggests that Hooke, who also had significant input to

40 See Yothers, op. cit. (16), for a comparison with captivity narratives from New England.

41 Autobiography, op. cit. (2), 5 (516).

42 Ferguson, op. cit. (17), 27 speculates that Hooke corrected the spelling and 'dressed' the language throughout.

43 Rubiés, op. cit. (7), discusses Hooke's preface with reference to drawing up heads of inquiry for travellers and instructions for the authors of natural histories. Alam and Subrahmanyam, op. cit. (6), note that the authorship of several European travel texts of this period is problematic, pointing to the co-authorship of the travel text of François Pyrard de Laval by Pierre Bergeron and the probable organization of the notes of JeanBaptiste Tavernier by the Protestant writer Samuel Chappuzeau.

44 Knox, Relation (interleaved), op. cit. (18), 194 (271). Knox, Historical Relation (ed. Paulusz), op. cit. (2) i, 383-92, speculates that the illustrator was Knox's brother, who died shortly before publication, perhaps explaining the unfinished appearance of some illustrations. Hooke's diary refers to purchasing Knox's prints from Edward Lascelles, Knox's brother-in-law, but noted that he was 'offended' with them (Henderson, op. cit. (19), 148, entry for 17 May 1681).

45 These include J. J. Saar, Ost Indianisge, Nuremburg, 1662 and 1672, which Paulusz (in Knox, Historical Relation (ed. Paulusz), op. cit. (2)) thinks served as a model for the wrongly proportioned elephant depicted in one illustration. The talipat palm depicted on page 15 is relatively accurate (M. C. M. Iqbal, personal communication), suggesting it was drawn with reference to the talipat leaf first shown to the society on January 1681.

46 As noted by Saparamadu, op. cit. (14), 'Introduction'.

47 Waasberge had in turn acquired plates from the map-maker Jansson. E. G. R. Taylor, 'Robert Hooke and the cartographical projects of the late seventeenth century (1660-1696)', Geographical Journal (1937), 90, 529-40, 539. Hooke's involvement is evident from his notes on the project in BL MS Sloane 1039 and from his correspondence with Leibniz on the subject (RS Early Letters, L5, M ${ }^{\circ}$ Leibniz to RH 18/20 January 78). Hooke also documents the project in his diary from 1675, in which he eventually referred to Pitt as a 'rascal' for his failure to deliver the promised payment for his involvement. See L. Rostenburg, The Library of Robert Hooke and the Scientific Book Trade of Restoration England, Santa Monica, CA, 1989. 
this project, might have had access to the original plates as well as to the published text in the Royal Society's library.

The draft second edition of the Relation gives a clearer indication of how the process of using guidelines, queries and other works may have functioned in the composition of the original text. For example, in one passage Knox notes that Hooke has a 'printed figure' of the coconut tree, before going on to describe in detail the tree's stages of growth and uses. ${ }^{48} \mathrm{~A}$ second passage enlarging on the process of tapping a coconut tree for toddy refers again to a picture of the tree, this time identifying it as coming from the Hortus Malabaricus. ${ }^{49}$ These questions are addressed in the interleaved sheets that follow. ${ }^{\mathbf{5 0}}$

Hooke's hand appears in the preamble and the first two chapters of the interleaved copy making editorial corrections and explanations, expanding a section concerning the medicinal use of leeches and speculating about why it tends to rain more in mountainous places. ${ }^{51}$ At the end of the text Hooke has added a list of queries for Knox to address. These include questions about various details of medicine, manufacture and the description of particular plants and topographical features in various locations, including Tonqueen and Mauritius. ${ }^{52}$ Hooke has again made small corrections and elaborations to the text that follows.

The process of questioning, editing and arrangement devoted to Knox's text by the Royal Society Fellows and other scholars was not unique, but is evident in several other works of the period. It is possible to see these guidelines for the composition of natural histories being put into practice in the production of two other contemporary publications: the East India Company surgeon John Fryer's account of his experiences in Persia and India, and Moses Pitt's English Atlas. ${ }^{53}$ The English Atlas was explicitly intended as a composite work; this is demonstrated by the public advertisement for any gentlemen with 'any curiosities of any country whatsoever' to bring them to be incorporated in the Atlas, if ' approved of and judg'd fit to be Printed by those Learned men, whose Judgements are consulted' ${ }^{54}$

If the Royal Society and other bodies were routinely consulted about the content of natural histories, the East India Company was frequently called on to provide patronage for their authors by financing the publication and through subscriptions. Knox's

48 Knox, Relation (interleaved), op. cit. (18), 93 (481).

49 Autobiography, op. cit. (2), 97-102 (497-502). 'Toddy' refers to tad̄̄, a popular spirit. See Yule, op. cit. (21), 927.

50 Autobiography, op. cit. (2), 97-102 (497-502). Paulusz gives the Sinhalese as Kalāgam Pattu.

51 Knox, Relation (interleaved), op. cit. (18), Part I, 1 (5).

52 Knox, Relation (interleaved) 235 (495-6). The passage is given in full in Iqbal, Raheem and Tennakone, op. cit. (13), 14.

53 J. Fryer, A New Account of East India and Persia 1672-1681, London, 1698 (also printed by Chiswell); M. Pitt, The English Atlas, 5 vols., Oxford, 1680-3. The fifth volume appeared without images; Moses Pitt was imprisoned for debt shortly afterwards.

54 M. Pitt, 'Advertisement about the English Atlas now printing at the theatre in Oxford by Moses Pitt Bookseller in London', in J. B. Tavernier, The Six Voyages of John Bapista Tavernier, tr. J. Philips, published by D. Cox. and printed for W. Gobbid and M. Pitt, London, 1677. 
dedication to the East India Company praises the company for bringing 'not only the Wealth but the Knowledge of the Indies ... home to us'. ${ }^{55}$ The company was certainly keen to amass information about Asia and Africa. Its archives are filled with descriptions of the physical geography, natural resources and contemporary political situation in many parts of the world. These descriptions include entire texts like that which Thomas Bowrey bequeathed to the company in his will or that which Samuel Baron sent to Hooke and Hoskins. ${ }^{\mathbf{5}}$ They also include the diaries of factors, lengthy passages in the letters and journals of the factories and the collections of books of advice, often based on the contributions of several different authors. ${ }^{57}$ The company's status was often uncertain during its first century of existence, and it was keen to be seen to benefit the nation by sponsoring the publication of useful information. French and Dutch works of the period exhibit a similar concern to claim that their work contributed to the national good. ${ }^{58}$

However, the circulation of information around European capitals and their settlements in the East Indies also raises the question of the tension between the urge to publicize claims to the knowledge and wealth of the Indies and the need to prevent, by enforcing secrecy, certain information from falling into the hands of European rivals. ${ }^{59}$ So most of the writing generated within the company, although often copied and circulated, was not published. In fact, most was closely guarded from European rivals, who tried equally hard to gain access. ${ }^{60}$ The competition over medicinal drugs and

55 Knox, dedication to the East India Company, published in Knox, Historical Relation (ed. Paulusz), op. cit. (2), ii, p. xxxviii.

56 T. Bowrey, A Geographical Account of the Countries Round the Bay of Bengal 1669 to 1679 (ed. R. Carnac-Temple), Cambridge, 1905; S. Baron. 'A Description of the Kingdom of Tonqueen', in A Collection of Voyages and Travels (ed. A. Churchill), London, 1732.

57 For a factor's diary see that of Hedges (Yule, op. cit. (3)), not intended to be entirely private or public, but apparently designed as a self-vindication aimed at the East India Company's directors. The journal of the Tonqueen factory for 1672-7 (BL MS Sloane 998) gives an extensive account of local politics. A good example of a book of advice is Senate House MS 56, which covers the period 1691-1732 and contains writings from a range of contributors from senior members of the company to supercargoes (private traders) to druggists. As shown by the location of this text, the books of 'advice' later became regarded as peripheral and are less well preserved than the vast archives of consultations and correspondence that remained in the India Office (now BL).

58 For example, Tavernier's dedication to Louis XVI reads, 'l'espère SIRE, que ces Relations exactes \& fideles que j'ai écrites depuis mon retour sur les Memoires que j'avois recueillis, ne seront pas moin utiles à ma Nation que les riches marchandises que j'ai raportees de mes voyages'. J. B. Tavernier, Les six voyages de Jean Bapiste Tavernier, Paris, 1666, 4.

59 See also D. Lach and E. van Kley, Asia in the Making of Europe, 3 vols., Chicago 1993-4, i, 151-4; and Rubiés, op. cit. (6).

60 For example, in a letter to England, the president at Surat notes that Tavernier, whom he describes as a 'Dutchified Frenchman', had been given passage to Persia several times on East India Company ships and had therefore been trusted by the Persian factory to carry their letters to Surat. However, Tavernier had then visited the 'Dutch house' (in Persia) and they, overcoming him with 'drink or persuasion', had 'possess'd themselves of the pacquet and in lieu thereof made up another seal'd with its subscription wrote by the originall ... imitating the English hand'. This counterfeit letter was then mixed in amongst some Dutch letters and returned to Tavernier (BL IOR E/3/29, 3144, ff. 152-62). 
recipes was especially fierce. As the drugster who boarded Knox's returning ship recognized, there were considerable profits to be had from acquiring the knowledge of the commodities that sailors and merchants had obtained through those they met on their journeys. ${ }^{61}$

European travel writing has been described as the simultaneous result of universalist and nationalist claims. ${ }^{62}$ The process of assimilation of the works of Baldaeus, Drakenstein and others into Knox's work continued with the translation, circulation, and reappropriation of the finished text. The translations of the Relation reorient it through the additions of new prefaces, dedications and illustrations. For example, the Dutch version is accompanied by a new illustration showing Knox's work being presented to the king of Kandy (Figure 1). This illustration also reminds us that travel texts in European languages circulated outside Europe, a point to be discussed in more detail below. In this case, it raises some interesting questions about how this depiction of the kingdom of their enemy Rajasingha II was received by the Dutch in Colombo. The geographical information provided by the Relation was certainly incorporated into Dutch maps in the years after its publication. ${ }^{63}$

The incentives to guard information closely should therefore be counterpoised against the importance of national claims when considering whether or not a manuscript was to be published. It is interesting to note that, in contrast to the fairly extensive and often unflattering coverage of Dutch relations with the court, the Relation makes little mention of English attempts to negotiate with Kandy. ${ }^{64}$ For the English company, Ceylon was a coveted site for trade, particularly in cinnamon. The company had made several attempts to treat with Rajasingha II to establish an alliance against the Dutch. These included letters sent under the pretext of attempting to free Knox and the other English prisoners. These attempts had been obstructed by the Dutch and forestalled by the rebellion of the king's son in $1664 .{ }^{65}$ With its description of the remaining English

61 Chakrabarti, op. cit. (2); L. Schiebinger, 'Prospecting for drugs: European naturalists in the West Indies', in Colonial Botany: Science, Commerce and Politics in the Early Modern World (ed. L. Schiebinger and C. Swan), Philadelphia, 2005, 119-33; L. Schiebinger, Plants and Empire: Colonial Biosprospecting in the Atlantic World, Cambridge, MA and London, 92-3, notes that the French Compagnie des Indes blocked British attempts to buy Michel Adanson's papers concerning the natural history of Senegal and that Hans Sloane guarded his recipe for curing sore eyes.

62 J. Elsner and J.-P. Rubiés (eds.), Voyages and Visions: Towards a Cultural History of Travel, London, 1999.

63 Bandara-Kosvatta appeared on Dutch maps soon after the publication of the Relation and the text was also drawn on for the 'Map of Ceylon surveyed along its length and breadth by order of the late Rt Hon'ble and Aurstere Ryklof van Goens', David Mill, professor of Theology at Utrecht, published by Joannes van Keulen, c.1710-12; cf. Knox, Historical Relation (ed. Paulusz), op. cit. (2), i, 442-5.

64 For example, in contrast to the version given by the Dutch records, Knox describes the conflict between the Dutch and Rajasingha after the expulsion of the Portuguese from Columbo in 1656 as having been due to Dutch treachery (Knox, op. cit. (1), IV, XIII, 179; see Paulusz's footnote to Knox, Historical Relation (ed. Paulusz), op. cit. (2), 452)). The Dutch are also described as being unable to match the king militarily and having to resort to flattery. Apart from the favourable description of a friendly ambassador, the Dutch inhabitants of Kandy are generally described as drunkards and addicted to vice (Knox, op. cit. (1), IV, XIII, 183).

65 A letter from Madras to the court dated 8 December 1664 (cf. Ferguson, op. cit. (17), 12) describes the Dutch blocking an English vessel sent to Cotiar and continues to say that the Madras factory had asked one of 

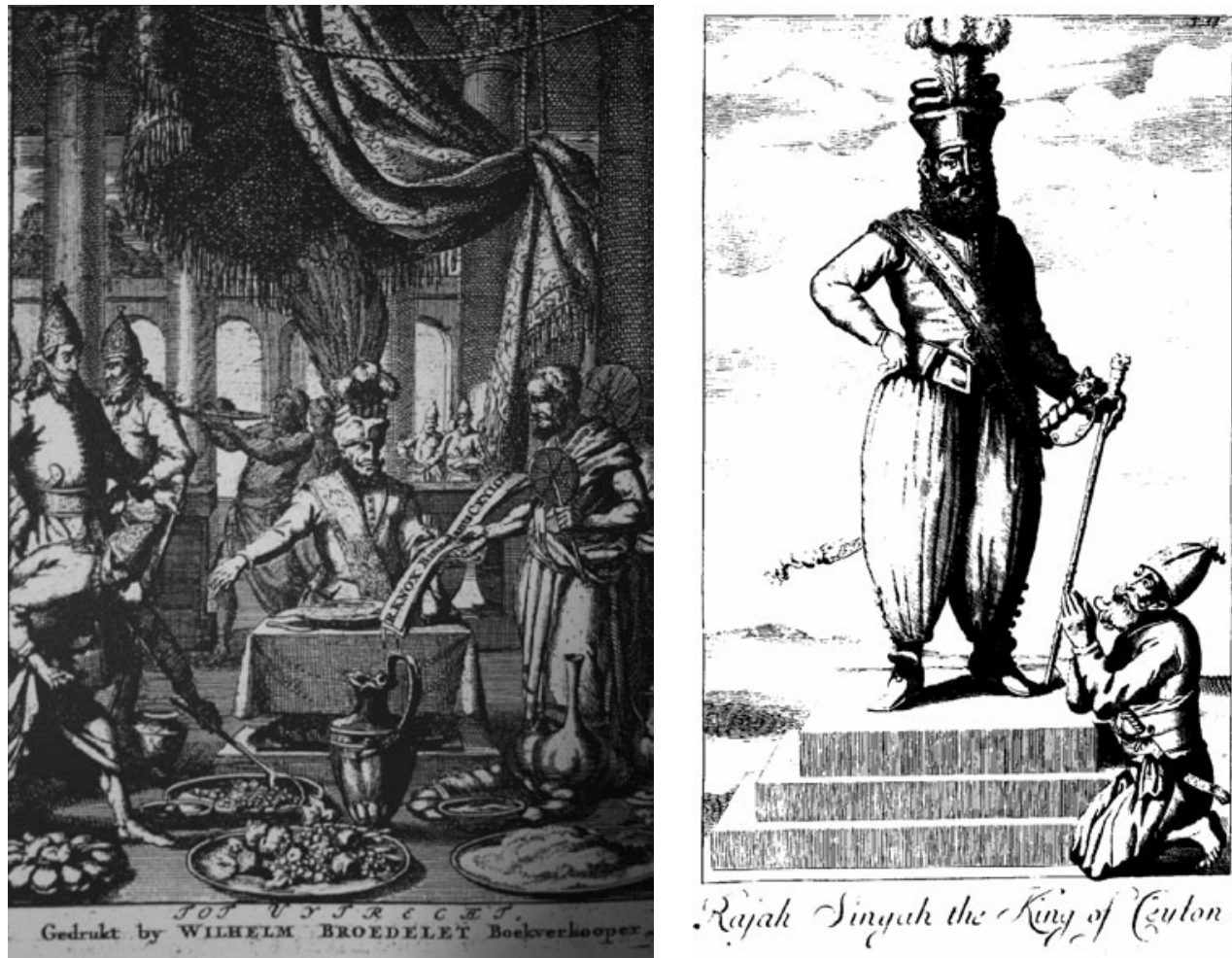

Figure 1. Left: frontispiece to Simon de Vries, 't Eyland Ceylon, in sijn binnenste, of 't Koningrijck Candy, Utrecht, 1692, printed by Wilhelm Brodelet. Right: Robert Knox, An Historical Relation of Ceylon, London, 1681, 32, 'Raja Singh the King of Ceylon'. Here and elsewhere in de Vries's translation, the central figure of the king in his Portuguese dress has been copied directly from that invented by the illustrator of Knox's text (33-4). Knox gives a precise description of the King's dress, but his facial features are not distinct from those of the other figures portrayed in the text. The courtiers' dress and the roundels (Hobson-Jobson, 170-1) they carry are taken from an illustration of Buddhist 'priests' in the Relation (75). Other details of the court setting are similar to illustrations in Baldaeus's Naauwkeurige beschryvinge van Malabar en Choromandel (Part II, before 1 and 18). A final curious point about this illustration is that the text of Knox's Relation is written on what seems to be a book made from talipat leaves, a Sinhalese technology of writing which Knox himself describes (109-10).

the captives, William Vassall, about the possibility of starting a factory and that the king of Kandy had written to Charles II on the matter. A section from the Dagh-Register of 30 January 1664 summarized by Ferguson (op. cit. (17), 13) describes Edward Winter's negotiations with Antonio d'Almeyda, a servant of Rajasingha II. See also London to Fort St George, 7 December 1669 (cf. Ferguson, op. cit. (17), 20) and London to Fort St George, 15 December 1676 (cf. Ferguson, op. cit. (17), 25), which combine inquiries about the captives and the possibility of opening up trade in cinnamon or acquiring cinnamon plants for transplantation to St Helena. In 1689 the factory at Fort St George made a further attempt, writing to Raja Devora of Tutecaree (from Tamil Tüttukkudi; see Yule, op. cit. (21), 946) 'desireing his intercession with the new King of Candy for the releasemt of the English Captives that were unhappily cast away on Zealoan as also proposals for a trade \& settlement in his Dominions, there being great quantities of pepper procurable there' (BL IOR G/19/6). 
captives, the Relation could even have served as a potential pretext for further interventions. ${ }^{66}$ Printed books therefore need to be regarded as part of a range of texts circulating on various levels of openness that informed the policy of the East India Company and scholars' investigations. The extensive translation of European travel texts, as exemplified by that of the Relation itself, meant, first, that rivals' texts would be closely scoured, reappropriated and 'corrected', and then that the most coveted information was often closely guarded. The next section explores how the often imprecise descriptions of medicinal plants and agriculture given in the Relation were used in Knox's unpublished manuscripts to form the basis of practical experiments in bio-prospecting and transplantation.

\section{The desirableness and facility of this undertaking - using the Relation (1): bio-prospecting}

Travel texts were meant to be read and used not only or even primarily in European capitals, but also in settlements abroad and during journeys. When travel books were taken on voyages, comparison between the written descriptions and first-hand experience took place, sometimes generating further written accounts. An example of this process is Baron's Description of Tonqueen, which, as he states, is partly an attempt to correct Tavernier's account. ${ }^{67}$ Baron composed his work in the East India Company's settlement at Madras, so this means that either he was carrying a copy of the Six Voyages with him, or that he consulted it in the library of Fort St George. Similarly, Allen Catchpole's discussion of the possibility of establishing a factory at Pulo Condore makes extensive comparisons with a work of William Dampier in his appraisal of the fruit and timber yielded by the local trees and also refers to Tachard's account of a voyage to Siam and an apparently unpublished description by Henry Smith. ${ }^{68}$

This process of comparison and 'improvement' is also evident in the use of the Relation. The Royal Society had several other contacts who possessed personal experience of Ceylon. The society used these men's accounts to compare with and enlarge on Knox's Relation. Paul Herman, Leiden professor of botany and employee of the Verenigde Oostindische Compagnie (VOC - the Dutch East India Company) in Ceylon, is first mentioned in the society's records in 1680 as preparing a catalogue of the plants of the island.$^{69}$ Herman's account was received at the society on its eventual publication in $1698 .{ }^{70}$ Herman exchanged specimens with Hans Sloane and his draft illustrations for

66 Autobiography, op. cit. (2), 63-4 (596-7) - a copy of a letter from Knox to his fellow captives in Ceylon, John Morgan and William Vassall. Knox reassures them that their circumstances have been 'published in print'. However, the letter also notes that there seems to be little current hope of intervention on their behalf and suggests that they resign themselves to remaining in Kandy. On these and the other English captives in Ceylon see E. Reimers, 'Raja Singh and his British captives', Journal of the Royal Asiatic Society Ceylon Branch (1925), 30, 13-36.

67 BL Sloane MS 1039, f. 133r.

68 BL IOR O.C. 8188, Condore, 8 July 1703, reproduced in Yule, op. cit. (3), pp. cccxxix-cccxxxvii.

69 'Hooke folio’ Royal Society Manuscript MS/847, f. 469 (16 December 1680).

70 P. Hermann, Paradisus Batavus, Leiden, 1698. Mentioned in JB, x, 24 August 1698. 
a second edition eventually came into the hands of James Petiver. ${ }^{71}$ In 1683 he sent his Vocabularium Selanense to Thomas Hyde, the Oxford orientalist and friend of Robert Boyle, who compared his transliterations of Sinhalese words with Knox's versions. ${ }^{72}$ The society was also in contact with a physician named Strachan who had lived on the island for seventeen years and published articles in the Philosophical Transactions concerning the use and transportation of elephants in Ceylon and on the religions, plants and wildlife of the island, in several cases drawing on Knox's work. ${ }^{73}$

A letter to his cousin Strype concerning the interleaved copy of the Relation reveals that Knox was also carrying his own text with him and making annotations on at least one of his subsequent journeys. ${ }^{74}$ It is not clear whether this was only during the first Tonqueen voyage via Cape Verde, Bantam and Batavia, or also during the second to Madagascar and St Helena. ${ }^{75}$ But there is evidence that on both voyages Knox referred back to the text, directed by questioning from members of the Royal Society and the practical instructions of the East India Company. In both cases, Knox's expertise on Ceylon expressed in the Relation was used to make comparisons between the island and other prospective sites for colonial settlement, trade or transplantation.

'Bio-prospecting' describes the process of examining and describing plants and identifying them, with the aim either of using them in situ or else of transporting them to other locations - botanical gardens in Europe or colonial plantations. ${ }^{76}$ The acquisition of plants that could yield drugs and food crops had a high potential monetary value and has been identified as a major factor in sixteenth-century Iberian political power, as well as in European colonial expansion in the New World. ${ }^{77}$ There is some

71 JB, x, 7 May 1701 and 25 February 1701/2. A copy of P. Herman, Museum Zeylonica, Leiden, 1717, with annotations by William Sherard, is preserved in the University of Oxford's Department of Plant Sciences (Sherard 157).

72 Knox, Historical Relation (ed. Paulusz), op. cit. (2), i, 400. For the comparison between Knox's and Hermann's vocabularies see Thomas Hyde to Thomas Bowrey, 7 February 1700, BL African and Asian Studies Dept, 763 mss Eur. E. 192. 2 f. 1.

73 D. Strachan, 'An account of the taking and taming of elephants in Zeylan, by Mr. Strachan, a physician, who lived 17 years there'; idem, 'Observations on the planting and culture of tobacco in Zeylan, by $\mathrm{Mr}$ Strachan'; idem, 'Observations made in the Island of Ceilan, by Mr Strachan on the way of catching fowl and deer, of serpents, of the antbear and of cinnamon'; idem, 'Some observations on coral, large oysters, rubies, the growing of a sort of Ficus Indica, the Gods of the Ceylanese, etc. Made in Ceilan, by Mr Strachan', all in Philosophical Transactions (1702/3), 23 (no page numbers).

74 Cf. Knox, Historical Relation (ed. Paulusz), op. cit. (2), ii, p. xv, referring to a letter dated 15 October 1713. The letter says that the interleaved copy was presented before the first journey.

75 A note in an unknown hand was added to Knox's preamble to the proposed second edition, stating that Knox had the book on the second voyage, had lost it along with his ship during the crew's mutiny on St Helena, and recovered it at Portsmouth on the Isle of Wight. Transcribed by Paulusz, in Knox, Historical Relation (ed. Paulusz), op. cit. (2), pp. xiv-xvi, who notes that the date given here for the presentation of the interleaved copy (1685) is incorrect based on the letter to Strype noted above.

76 E. Spary, 'Of nutmegs and botanists: the colonial cultivation of botanical identity', in Colonial Botany: Science, Commerce and Politics in the Early Modern World (ed. L. Schiebinger and C. Swan), Philadelphia, 2005, 187-203.

77 F. Guerra, 'Drugs from the Indies and the political economy of the sixteenth century', Analecta MédicoHistórica (1966), 1, 29-54; C. Mukerji, op. cit. (6); M. T. Bravo, 'Mission garden, natural history and global expansion, 1720-1820', in Colonial Botany: Science, Commerce and Politics in the Early Modern World (ed. L. Schiebinger and C. Swan), Philadelphia, 2005, 49-65; and Schiebinger op. cit. (61), 73-4, discuss the 
debate about the comparability of European investigations of plants that could provide food and drugs in the East Indies and in the West Indies. Both programmes involved exchanges with 'informants', involving varying degrees of consent and cooperation. ${ }^{78}$ However, some scholars have argued that, in contrast to the largely oral exchanges that took place in the West Indies, in the east the European contribution consisted largely of compiling or rearranging south Asian knowledge that had been previously systematized and recorded. ${ }^{79}$

Knox's Relation contains no direct reference to written medical texts or specialists. ${ }^{80}$ A ritual that would have been performed by a priest as part of a cure is mentioned twice. ${ }^{81}$ Furthermore, there is no reference to the influence of any system of medicine that may have resulted from the presence in Kandy of Muslim traders from the Malabar coast, nor to any imported medicines. Probably because its author lived mostly in rural areas rather than in the city or court, the Relation concentrates its short section on medicinal plants on household medicine using simples: 'The woods and trees are their Apothecaries Shops, where with Herbs, Leaves they make all their Physic and Plaisters, with which they sometimes they will do notable cures.' Rather than listing these medicines, 'of which there are hundreds', Knox simply notes the cure of a broken arm with unspecified herbs and his own cure of a sore throat by chewing the bark of the 'Amaranga tree'. ${ }^{22}$ In the interleaved version, Knox expands on the preparation of a simple from this bark 'as I was instructed by one of the C[o]untry men'. The survey of edible plants, whether wild or cultivated on a small scale for food, is similarly perfunctory. He notes the existence of two types of aloe, gives the Sinhalese names for four other vegetables and mentions that several European herbs have already been transplanted, from 'which I perceive all other European plants would grow here' ${ }^{83}$

European concern over the drain of money to the East and West Indies as the new cures became increasingly popular. Linnaeus commented that ' it is horrifying to reflect that a poor man here at home can hardly be given a purgative without it being prescribed from the East or West Indies'. Cf. L. Koerner, Linnaeus: Nature and Nation, Cambridge, MA and London, 1999.

78 See Schiebinger, op. cit. (61).

79 See, for example, the preface of Drakenstein's Hortus Malabaricus for the acknowledgements of the contribution of Itty Achuden's work and the book Manhaningattnam. However, as Manilal also notes, no manuscript in Malayalam or Sanskrit that corresponds with the description given has so far been discovered. K. S. Manilal, 'The implications of HM', in History and Botany of Hortus Malibaricus (ed. K. S. Manilal), New Delhi, 1980, 1-5. For further discussion see Raj, op. cit. (6).

80 This does not, of course, imply that the information of Knox's informants could not be ultimately traced back to Sinhalese Buddhist variations on Ayurvēdic medicine, with its extensive pharmacopoeia, or to the knowledge of the village-level medical professionals (vedarāla).

81 Knox refers in the interleaved version to the dedication of food to demons, noting that he himself became ill after eating a cock dedicated to these demons (f. 184, inserted after Part III, Chapter XI, 144). See G. Obeyesekere, 'The ritual drama of the Sanni Demons: collective representations of disease in Ceylon', Comparative Studies in Society and History (1969), 11, 174-216, for discussion of the Kōla Sanniya ritual; and B. Kapferer, A Celebration of Demons: Exorcism and the Art of Healing in Sri Lanka, 2nd edn, Oxford, 1991. And for a critique of these approaches see D. Scott, Formations of Ritual, Minneapolis, 1994.

82 Knox, Historical Relation (ed. Paulusz), op. cit. (2), ii, 75, note 1, identifies this as Kāmaranga, Lat. Averrhoa carambola (family Oxalidaceae). The identification was confirmed by the director of the National Botanic Gardens of Sri Lanka.

83 Knox, op. cit. (1), I, V, 19 (see Knox, Historical Relation (ed. Paulusz), op. cit. (2), 74, note 3, for identification of the plants for which Knox gives the approximations of the Sinhalese names). 
Despite the Relation's lack of detailed descriptions of edible and medicinal herbs and plants, a comparison of the original with the interleaved copy and with the truncated journal of Knox's voyage to Tonqueen in 1681 demonstrate that he was involved in bioprospecting for naturally occurring plants yielding drugs and food by comparing the plants growing in Cape Verde with those of which he was aware in Ceylon. The plant in which the process of bio-prospecting and transplantation can be most clearly traced across these three texts is the 'jack', a name used both for the tree and for its fruit. In the Relation the following description is given:

There is another Fruit, which we call Jacks; the Inhabitants when they are young call them Polos, before they be full ripe Cose; and when ripe, Warracha or Vellas; But with this difference, the Warracha is hard, but the Vella as soft as pap, both looking alike to the eye no difference; but they are distinct Trees. ${ }^{84}$

The fruit is described here as a foodstuff: 'they are a great help to the People, and a great part of their food', being compared to a turnip or cabbage, with the thick white juice being used to catch birds.

In his account of the 'I[s]le of May' (Maio, Cape Verde), Knox also describes the type of jack yielding 'warracola', this time revealing a medicinal use for the fruit, although omitting the description of the tree itself. He notes,

The leafe resembles a Cabbage both in thickness \& colour; onely not so large. It is ful[1] of white thick milk, or juice, if you break the leaves which is soon done, being very brittle. The Chingulais put to many medicinal uses: $\&$ here in this I[s]land of May they grow in great plenty, just above the sand on the sea shore.

Knox argues that the plants were probably indigenous rather than transplanted, since the inhabitants, whom he correctly assumed were mainly transported from around the Gulf of Guinea as slaves during the period of Portuguese rule, appeared to be unaware of many of their medical uses. He goes on to link the types of plants that are likely to prosper relative to the positions of the two islands, noting that

the difference of Longitude doth not much chang or alter the nature of the Climate as the Latitude doth. For notwithstanding Zeilon Lyeth Degr. $\log 1 / 2$ to the Eastward of this Iland, yet here I saw several Plants growing wild, wch grow in the same manner upon Zeilon.

As well as describing two other plants, 'Bintombracole' and 'Endraatta', growing both on Ceylon and May, he also discusses the neighbouring island of St Iago (Santiago), where he notes plants common throughout the East Indies such as oranges, limes, coconuts, grapes, plantains and watermelons, as well as briefly discussing the effect of the soil type on the native flora. ${ }^{85}$

84 Knox, Relation, I, IV, 14. Paulusz identifies the 'jack' with Artocarpus integrifolia, from the Portuguese jaca, 'warracha' with Sinhalese varāka, and 'vella' with vāla (Knox, Historical Relation (ed. Paulusz), op. cit. (2), ii, 50, note 2). According to the director of the National Botanic Gardens of Sri Lanka, all in fact come from the same jack tree, Artocarpus heterophyllus.

85 BL MS Lansdowne 1197; underlining in original. Bintombracole is identified by the director of the National Botanic Gardens of Sri Lanka as Ipomoea pes-caprae (Linn.) Roth. (family Convolvulaceae). He identifies Endraatta as castor Ricinis communis (family Euphorbiaceae), one of the most poisonous plants in the world. 
In the interleaved copy of the Relation Knox describes the jack tree in much more detail. As well as its value as a foodstuff, he mentions the strength of its roots and the hardness of its timber, which he compares to that of the English oak, and notes that it is used as a building material for houses in Ceylon. ${ }^{86}$ In the same copy Knox mentions that the people of Ceylon are not familiar with grafting, perhaps implying that he himself had tried this technique. Finally, he notes a failed attempt to transplant the jack:

I brought one younge plant to the I[s]land of [Barbados] and it was planted in Jehew Halls plantation, but the head haveing been twice [broken] of[f] in my passage the[re]after it died, [else] I doubt not but it would have grown to the great benefitt of the [inhabitants] of the $\mathrm{I}[\mathrm{s}]$ land which was my onely end. ${ }^{87}$

Knox's discussions of the jack tree and its products in these three passages serve several functions. The survey of the Cape Verde islands can be regarded as part of the East India Company's search for potential bases in the Atlantic Ocean. One of the company's projects during the late seventeenth century and the early eighteenth was to establish a chain of settlements in the Atlantic and Indian Oceans like St Helena or the Dutch factory at the Cape and the later French settlements in Madagascar and Mauritius. ${ }^{88}$ These bases were intended to function as small plantations, supply bases for ships trading to both the East and West Indies, and points of defence. ${ }^{89}$ Knox's account of Cape Verde is clearly geared towards this objective. He includes accounts of the fortifications and buildings, as well as possible products, such as cotton, which he observes the inhabitants produce by spinning it with a stick, again comparing it to the method used in Ceylon. In addition, he gives a brief (and unflattering) account of the inhabitants. ${ }^{90} \mathrm{~A}$ similar example was the company's instructions to Knox to make an 'exact survey' of Tristan da Cunha, giving an account of harbours, vegetation and animals and presenting an opinion on whether it would be 'advantageous for the Company hereafter to make settlement upon any of those Islands', which 'Capt Gayez $\&$ others inform us would save the lives of many men' ${ }^{91}$ This commission was again to be undertaken using an earlier text containing advice, in this case the unpublished journal of a ship's mate who had landed at the island the previous year. ${ }^{92}$

86 Knox, Relation (interleaved), op. cit. (18), folios inserted after I, IV, 18 (61-2).

87 Knox, Relation (interleaved), op. cit. (18) (63-4). The location of 'Jehew Hall' is not clear.

88 See R. Grove, Green Imperialism, Cambridge, 1995.

89 The East India Company's relationship with the colonies in the West Indies was ambiguous: ships from the Americas supplied them with silver and sugar and were a useful source of slaves for St Helena (SHA Council Books, ii, ff. 146 and 167). However, the company officially regarded English ships trading in slaves from Madagascar to these colonies as infringing their monopoly and launched actions in Parliament to prevent the trade after allegations in 1695 that these traders were supplying the pirates who attacked the Mogul fleet in the Red Sea. After a ban in 1698 the trade was resumed until 1716, but then prohibited again after the company had been denied the right to engage in the slave trade to America themselves. See V. B. Platt, 'The East India Company and the Madagascar slave trade', William and Mary Quarterly (1969), 26, 548-77.

90 BL MS Lansdowne 1197.

91 'Instructions to Captain Knox', London, 4 April 1684, BL IOR E/3/90 ff. 182-3. In his autobiography Knox notes that he reached the latitude of Tristan da Cunha but was unable to land there due to bad weather and lack of time. 'Captain Gayez' refers to John Gayer, who was given a commission similar to Knox's to survey Tristan da Cunha (P. Stern, personal communication).

92 'Instructions to Captain Knox', op. cit. (91). 
This instance of 'bio-prospecting' on Cape Verde can thus be seen as part of an ongoing speculative survey of several possible bases for the East India Company. The search for food and drugs was coupled with an analysis of the defensive capabilities of the island, its potential for manufacturing cotton or extracting natural resources such as ironstone, and its capacity to supply a workforce, whether through independent trade or free or coerced labour. ${ }^{93}$ The race to identify, settle and defend suitable island bases was run against the Dutch and French East India Companies, who were making similar surveys in this period. ${ }^{94}$ These trading companies were also competing for those islands that had already been settled..$^{95}$

At the same period, the Royal Society was engaged in a number of investigations about the effects of longitude and latitude, as well as climate, altitude and soil type, on plant and animal life and even disease ${ }^{96}$ It therefore seems likely that Knox's discussion in his later texts of plants that grow in distant places with similar latitudes, and his account of grafting, were developed through his contacts with these scholars. Such theories had obvious implications for the types of plant to be sought in the process of bio-prospecting, as well as for the types of crop that were likely to be transplanted effectively. Thus the development of scientific theory regarding the natural world was inextricably linked to European expansion and proto-colonialism. ${ }^{97}$ These processes, with their allied claims to both national supremacy and international scope, also had religious connotations. ${ }^{98}$ Such implications can also be identified in Knox's presentation of the jack, coconut and plantain trees as 'the most wonderful things that God's hands hath wrought'. ${ }^{99}$

93 As Grove, op. cit. (88), notes, Drake also landed at St Iago in Cape Verde, and the account published in 1683 gives a far more enthusiastic account of the island than Knox's.

94 For an account of the French ambassador de la Hays's survey of possible sites for the Compagnie des Indes in the Indian Ocean after returning from Ceylon (where he had attempted to 'settle a trade' but failed after offending the king - Knox gives an account of this and his later meeting with him in London; IV XIV), see Du Bois, Les voyages fait par le Sievr D B, Paris, 1674. See A. du Quesne, A Voyage to the East Indies in the Years 1690 and 1691, London, 1696, for the brief settlement by French Huguenot refugees of the island of Rodriguez, near Mauritius. The reference in Hooke's diary (BL MS Sloane 4024, entry for 24 October 1689) to Diego Rodriguez after a conversation with Knox also describes it explicitly in terms of a potential settlement.

95 The Dutch and Portuguese fought battles over the island of St Helena from 1625; the Dutch formally claimed it in 1633 and held it from January to May 1673. See S. B. Royle, The Company's Island: St Helena and the Colonial Endeavour, London and New York, 2007, 153-5. For the suggestion in 1715 of Governor Isaac Pyke of St Helena that the English claim Mauritius, recently abandoned by the Dutch, and transplant the population of St Helena there explicitly to keep the island from falling into the hands of the French inhabitants of Reunion Isle, see P. Gosse, St Helena 1502-1938, London, 1938, 137-8.

96 See, for example, W. Cockburn, Diseases of Seafaring Men, London, 1696, for the classification of diseases according to meridian.

97 Cañizares-Esguerra, op. cit. (7), notes the emergence of natural philosophy alongside Iberian colonialism from the fifteenth and sixteenth centuries. See also Guerra, op. cit. (77).

98 Grove, op. cit. (88); and Mukerji, op. cit. (6).

99 Autobiography, op. cit. (2), 96 (635). See also Relation (interleaved), op. cit. (18), folios interleaved before 192 (493-5). The emphasis on the utility of the tree to mankind seems to be a reaction to the praise heaped on the spice trees, the products of which Knox regarded as rather frivolous, by earlier Portuguese and Dutch writers. 
The Relation is a work in two parts: natural history and personal account. Although the text should be regarded as a composite work with considerable input from European scholars, this does not negate either the presence in the text of Knox's personal outlook or the effects of ideas received during the nineteen years he spent in Ceylon or in his subsequent travels. Indeed, Knox's responses to the questions put to him by scholars such as Hooke and his contribution to bio-prospecting on behalf of the East India Company should be examined with reference to his personal interactions with members of the societies he visited. ${ }^{100}$ Knox was in Ceylon for nineteen years, during which time he adopted the local language, dress and way of life. ${ }^{101} \mathrm{He}$ also raised a child; in fact, it was his return to Europe rather than this level of assimilation that was unusual. ${ }^{102}$ Knox's identification of himself as a member of Kandy society is evident in his language in the description of Cape Verde. At one stage he describes a plant, Allacola, 'which wee have on Zeilon'. ${ }^{103}$ This perspective also colours his account of his subsequent travels. For example, from Knox's perspective as a resident of Kandy the inhabitants of Cape Verde are dismissed as lacking in 'ingenuity'. Rather than inquiring into their own medicines and industries or taking into account their enforced migration, he assesses them based on the knowledge of the particular plants he recognizes from Ceylon, and from the viewpoint of a transitory visitor rather than a resident. The customs of Madagascar similarly receive a less than complimentary treatment in Knox's writings. ${ }^{104}$

\section{The desirableness and facility of this undertaking - using the Relation (2): transplantation}

As well as surveying potential bases for naturally occurring foods and medicines, the East India Company was also involved in attempts to transplant both agricultural and manufacturing techniques from both the West and the East Indies. These efforts were based on consultations with 'experts', books and manuscripts in London and involved transporting both people and texts around the company's settlements. Consultations in London encompassed a range of people from merchants like Thomas Bowrey, scientists such as Robert Boyle, and an unnamed man from Mauritius whom Knox was ordered

100 Raj, op. cit. (6), 252, notes that these relationships are the missing element in many discussions of the interactions between European 'sedentary men of science' and the travellers who answered their inquiries.

101 Knox told the Dutch that he was able to escape because, knowing the language and wearing Sinhalese clothing, they were 'not regarded as Europeans', or were seen as Portuguese, who were sufficiently integrated not to wish to leave. De Vos, op. cit. (1), 187. See also Boxer, op. cit. (16).

102 Knox, Relation (interleaved), op. cit. (18), IV, VIII, 152, (396); and Autobiography, op. cit. (2), 63-4 (596-7), for Knox's adoption of a female child, Lucea, whom he taught to read and write English and to whom he bequeathed his land and possessions and later sent his picture. For the marriage and settlement in Kandy of his fellow captives, see Relation (interleaved), op. cit. (18), I, VII.

103 BL Lansdowne MS 1197. This appears to be an unconscious deviation from his normal 'the Chingulais have ... ', but perhaps all the more revealing as such. Knox gives the following description of Allacola: 'it bears a broad leaf, somewhat like a Heart. The Chingulays bo[i]l [them] \& eat [them] but this people understand [them] not'.

104 See Autobiography, op. cit. (2), 9-23 (537-51). Knox's description of Madagascar is another element of his later work that warrants more attention. 
to bring before the Court of Directors in $1690 .{ }^{105}$ The exchanges also drew on developing theories about the effects of latitude in order to select suitable crops for transplantation. For example, in 1682 the directors noted in a letter to St Helena that 'we have discoursed with many persons and we know that very good [wheat] doth grow in many parts of the world with latitude similar to yours'. ${ }^{106}$

To effect the movement of experts, the company employed techniques ranging from persuasion via material incentives to coercion, depending on their relative status in a particular area. In 1685 a request was sent to the Bombay factory to supply St Helena with slaves skilled in sugar plantations and the manufacture of saltpetre. ${ }^{107}$ In 1666 an attempt to persuade growers of indigo from the area around Surat to move to the island to demonstrate their skills had failed. ${ }^{108}$ A comparable attempt in 1689 and 1690 to induce a group of French Huguenot wine growers to come to the island to plant vines was, however, successful - although the experiment itself proved short-lived. ${ }^{109} \mathrm{Knox}$ was involved with this transfer of expertise from the East and West Indies in several ways. After the reluctance of the Surat indigo growers to comply with the company's request, a West Indian cultivator had been brought in to demonstrate the farming of indigo. ${ }^{110}$ Knox was then instructed to procure indigo and cotton seeds from Madagascar to be sown under the supervision of this planter. ${ }^{111}$ As well as the journal of Captain Bass, on the basis of which the company urged the establishment of salt works, Knox also carried a written set of rules that the company had sent from Barbados and which they were instructed to implement with regard to the slaves whom Knox was to transport from Madagascar. ${ }^{112}$

Based on his own descriptions of agriculture in Ceylon in the Relation, Knox was also intended to contribute to the company's attempts at the transplantation of crops. The description of agricultural techniques in the original text is more extensive than that devoted to medicinal plants, and focuses in particular on rice cultivation. Rice production in seventeenth-century Kandy was organized on a village level, with

105 BL IOR B/40 (Court Minutes 1690-1695) f. 15, 12 September 1690 - 'It is ordered that Capt. Knox do bring into this Court the Negro that was brought home on his ship from the Mauritius to be examin'd touching his coming away from that island'. (There is no indication of whether this instruction was followed; it is not mentioned in the next meeting.)

106 London to St Helena, 1 August 1682. BL IOR E/3/90, f. 87r-88; also cited in Royle, op. cit. (95), 27.

107 London to Bombay, 5 March 1685. BL IOR E/3/90, f. 158. See also Royle, op. cit. (95), 24-5.

108 Sir George Oxenden and council in Surat to East India Company in London, 1 January 1666, BL IOR original correspondence, 3144, (E/3/29, ff. 152-62). Oxenden notes that they have sent indigo seeds to St Helena, but 'we cannot possibly gett a person here to direct them in the sowing \& making indigo: those that plant it here being all natives $\&$ have families, who will not be persuaded to leave them $\&$ their Relations on any consideration, which we thought good to advise you of, that you might endeavear the procuring of a Person or two out of those plantations of Barbados etc.'.

109 A list is given in SHA, CB, iii, f. 132 (145), of those arriving with Stephen Poirier in January 1690. See Gosse, op. cit. (95), 102-3. On other attempts to transplant various techniques see P. Stern, 'Politics and ideology in the early East India Company-state: the case of St Helena, 1673-1709', Journal of Imperial and Commonwealth History (2007), 35, 1-23.

110 Royle, op. cit. (95), 79-80.

111 BL IOR E/3/90, ff. 182-3.

112 BL IOR E/3/90, f. 175, London to St Helena, 5 April 1684/5. For discussion of slavery on St Helena see Royle, op. cit. (95), 84-103. 
paddy lands worked communally and a portion of their produce set aside for the king's storehouses. ${ }^{113}$ Knox describes the creation of these paddy fields by the management of water. He notes and names five different types of rice requiring various amounts of time to ripen. ${ }^{114} \mathrm{He}$ explains that the type to be sown will be selected depending on how long the necessary amount of water is likely to be available and the approach of the time of year when the fields are due to revert to grazing land for cattle. ${ }^{115}$ Finally, he mentions that there is a type of rice that can be grown without permanent submersion on high lands that cannot be flooded with water. Knox goes on to describe the preparation of the fields using light ploughs drawn by oxen, the cooperation of the villagers in reaping the harvest and the method of treading out the grain using oxen. ${ }^{116}$ The interleaved version of the text again expands on this section, giving more detailed instructions and in one passage providing a diagram of a tool used to channel water. ${ }^{117}$

On the basis of Knox's account of the rice variety that ripened without standing in water, in addition to the oral advice of Knox and 'several others', the directors formulated a plan to sow this variety on the highlands of St Helena. ${ }^{118}$ In 1684 they ordered their agents in Surat to acquire 'three or four baggs of fresh Paddy, of that particular Kind ... wee intending it for seed at St Helena'. ${ }^{119}$ The letter goes on to give instructions to store the rice in a cool cabin during the journey and to transfer it between bags at least once a fortnight in order to 'preserve its prolific quality'. The letter to Surat stresses the potential value of the crop, which is described as 'no meane concerne to this Kingdom'. ${ }^{120}$ Knox and a former fellow captive were then instructed to oversee the sowing of the rice. The directors in London informed their council in St Helena,

there is a peculiar sort of Rice that groweth best on high and dry Lands, the seed and cultivation whereof he knoweth very well. He and Ralph Knight that is on board his ship having wrought many years upon it with their own hands in Ceylon. ${ }^{121}$

113 Wickremesekera, op. cit. (12), 50-3.

114 K. N. Chaudhuri, Asia before Europe, New York, 1990, 238, notes that it is hard to assign a date to the original development of quick-ripening rice (which allows for a double crop in a year), but that it seems to have been introduced from the ancient kingdom of Champa to China in around 1012 and spread from there to South Asia.

115 Knox, op. cit. (1), I, III, 8, notes that during the designated rice season 'their fields are all in common', but that after this period, the various owners of the land let in their cattle, meaning that any rice not harvested would be destroyed. See Knox, Historical Relation (ed. Paulusz), op. cit. (2), ii, 34, note 1, for an identification of the types of rice.

116 Knox, op. cit. (1), I, III, 9-12.

117 Knox, Relation (interleaved), op. cit. (18), folios inserted between 9-12 (37-46).

118 It is not named in the original; Paulusz (Knox, Historical Relation (ed. Paulusz), op. cit. (2), ii, 37, note 1) speculates that it may refer to Suvanda-āl. In the interleaved copy, Knox names two types: one with a red husk called 'Kere-All-wea' and the other with a white husk known as 'Meputt-all-wea', interleaves inserted after 9 (37).

119 BL IOR E/3/90, f. 170, London to Surat, 7 April 1684.

120 BL IOR E/3/90, f. 170, London to Surat, 7 April 1684.

121 BL IOR E/3/90, f. 175, London to St Helena, 5 April 1684. The East India Company display more concern for the conservation of timber here than Grove, op. cit. (88), generally credits them with in the early period, noting that 'we will never permit any to be made on $\mathrm{yo}^{\mathrm{r}}$ Island lest it should consume $\mathrm{o}^{\mathrm{r}}$ wood'. 
Knox was also intended to demonstrate the uses of coconut trees; instructions from London implied these were growing on the island. ${ }^{122} \mathrm{He}$ was supposed to demonstrate how to draw the oil, which is compared to the oil of almonds. This process is described in the interleaved version of the Relation, as well as in the Autobiography. ${ }^{123}$ A final lesson drawn from the Relation relates to the production of iron. The directors note that Knox believes that ironstone is plentiful in St Helena and that 'in the Country where he was captive, every poor man ... made his own Iron for the use of his family'. Knox was instructed to demonstrate the technique in the hope that the stone could be transported to India and manufactured there. ${ }^{124}$

Rice was clearly an important foodstuff on St Helena in the early period, and its transport and storage seem to have been difficult. References in the early records are made to shortages and poor store quality. ${ }^{125}$ An earlier proposal to send two slaves experienced in cultivating rice paddies had already been dropped after advice that the crop was unsuitable for the high ground of St Helena. ${ }^{126}$ This motivated the choice of the specific type of rice that it was intended Knox supply. However, it is unclear whether Knox ever put into practice the intended experiments in rice growing, the production of iron or the growing of cotton and indigo. ${ }^{127}$ In fact, Knox's most important contribution to the development to the island was probably as a slave trader. He arrived at St Helena with at least two consignments of slaves from Madagascar. Slaves were often valued not only for their labour but for their expertise in growing the types of crop the company wished to establish on St Helena. ${ }^{128}$ Transplantation of people was carried out alongside that of plants. Like his description of Ceylon, Knox's account of his visits to Madagascar in the draft second edition would have been intended for the use of other traders.

As with the example of the jack tree, the discussion of Knox's involvement with the attempted transplantation of rice is only the most traceable example among several indications that Knox was involved in transplantation around the settlements he

$122 \mathrm{BL}$ IOR E/3/90, f. 175, instructs 'cherish and increase yo ${ }^{\mathrm{r}}$ Coco-nut trees all that possibly you can, they being of much more use than you doe at present apprehend'. Whether coconut palms were in fact established is uncertain. P. Ashmole and M. Ashmole, St Helena and Ascension Island: A Natural History, Shropshire, 2002, 74 and 440, note that the fossil evidence from St Helena shows that palms were once important; they appear to have been extinct for some time with a few surviving date palms that were planted in the sixteenth century by the Portuguese. J. C. Meliss, St Helena: A Physical, Historical and Topographical History of the Island, London, 1875. R. O. Roberts, "The plants of St Helena Island" (unpublished MS notes compiled during the 1970s), mentions four types of palm but not the Cocos nucifera. Gosse, op. cit. (95), 169, mentions that coconuts sent from Bombay were planted by Pyke in 1733-4.

123 Autobiography, op. cit. (2), 100 (641).

124 London to St Helena, 5 April 1684, BL East India Company Original Correspondence E/3/90, f. 175.

125 SHA, CB, ii, f. 52 (48), 11 April 1684.

126 SHA, Letter Book, i, 23 January 1679; see also Royle, op. cit. (95), 87.

127 Knox does appear in the St Helena records, where he was made a temporary member of council (SHA Consultations, ii, f. 164 07/05/1685) and entered a petition for support and a passage home after his men, who had been drinking punch and cursing Knox as an 'old Portuguese rogue', made off with the Tonqueen Merchant (SHA Consultations, ii, f. 175 08/06/85).

128 See, for example, E/3/90, ff. 182-3, in which Knox is advised to 'give encouragement to the natives of Madagascar to plant cotton'. 
visited. ${ }^{129}$ Whether or not it was eventually implemented, Knox's commission was one of a long series of agricultural experiments on St Helena that began with the Portuguese introductions of the fruit trees at which early travellers marvelled, as well as of the European plants and herbs brought during their initial colonization of the island in 1502. The English fleet sent to colonize the island in 1659 was instructed to stop at Cape Verde to pick up specimens of cassava, yam, potatoes, beans and chickpeas, as well as orange and lemon trees, for transplantation. ${ }^{130}$ Attempts to transfer plants and techniques from the Indian and Atlantic Oceans to St Helena continued until the twentieth century with mixed results. Some successes included yams, New Zealand flax and coffee. ${ }^{131}$ Others such as rice and cinchona (the source of quinine) never became established. ${ }^{132}$

London scholars also continued to play an advisory role in these experiments. Several governors sent species to London, and Joseph Banks, Daniel Solander, William Roxburgh and William Hooker would all later investigate the island's plant species. ${ }^{133}$ The East India Company also continued to receive advice about the suitability of crops for transplantation based on the latitude at which they were found. For example, Joseph Banks's recommendations about the transplantation of tea to certain areas of India were based on previous writings about the types of tea growing at similar latitudes in China. ${ }^{134}$ Often, however, the failure or success of such schemes seems to have been due to social rather than environmental factors. For example, the company apparently gave no thought to the logistics of transplanting to St Helena the system of cooperative rice growing that Knox describes in Kandy, where agricultural production was based on a combination of landowning 'free planters' and company plantations, both depending on slave labour.

\section{Conclusions}

Investigation of the production and circulation of Knox's Relation illuminates several points about the place of travel texts and natural histories in the process of European expansion and in the development of ideas about the effects of latitude on plants and people. The involvement of Strype and Hooke in the first and second editions shows how questioning, comparison and appropriation of other accounts helped form

129 For example, the list of items brought to the Royal Society in 1683 includes the 'root of a tea tree, which the Captain designing to bring home growing had planted, and kept in a pot of earth aboard the ship, but which, by the way was gnawed and killed by the rats'. Birch, op. cit. (21), ii, 226.

130 W. Foster, 'The acquisition of St Helena', English Historical Review (1919), 34, 281-9.

131 Yams were probably one of the earliest introductions and a staple diet by the 1670s; see SHA, CB, i. For flax and coffee see Stern, op. cit. (109), 41; Royle, op. cit. (95), 28-9. Both were briefly profitable but flax, like many other introduced species, soon became considered detrimental to the survival of indigenous and endemic plants.

132 Yams were introduced at around the time of original settlement and became an important foodstuff; cinchona was introduced in 1867-8 but did not thrive. Ashmole and Ashmole, op. cit. (122), 156-7.

133 Ashmole and Ashmole, op. cit., (122), 65-7.

134 Joseph Banks to William Devaynes, 27 December 1788, British Library MS D993 (India Office private papers). Transcribed in N. Chambers (ed.), The Letters of Sir Joseph Banks, A Selection, 1768-1820, London, 2000, Letter 35, 114-19. 
composite 'natural histories' with several applications. Cooperation between the East India Company and the Royal Society in producing this text should be viewed as part of an ongoing collaboration between the two institutions to lay claim to the wealth promised by amassing useful knowledge about the world. Such claims were important in establishing the authority of both organizations. They also formed part of competition with the French and Dutch to lay claim to that knowledge as well as to the wealth of the East and West Indies on behalf of the nation. Other examples from the same period include the published works of Fryer and Dampier, as well as the unpublished letters, responses to questions and descriptive accounts that fill the archives of both the society and the company. By providing merchants and travellers with queries, guidelines on making observations and instruments such as those Hooke gave Knox, scholars could amass information that returned as advice to the company's agents about appropriate crops or medicinal plants likely to flourish at certain latitudes or under particular environmental conditions. The advice also appeared in the forms of guidebooks or 'natural histories', maps and dictionaries. Some aspects of the contemporary uses of Knox's work, including the incorporation of its linguistic content in dictionaries and of its political and religious content in contemporary philosophy, fall beyond the scope of this paper. Other Knox manuscripts, such as the journal Hooke mentioned in 1684, remain to be identified, precluding an analysis of how the information he provided about tides could have been used in sea charts. It is nevertheless clear that, just as Hooke predicted in his preface, the information provided by Knox was drawn on by specialists in a number of fields.

To locate Knox's Relation within a range of published and unpublished manuscripts produced by collaboration between merchants and scholars in the late seventeenth century also allows a clearer picture of how such texts were used to explore the possibilities of transferring non-European practices and techniques to European settlements like St Helena, or of identifying other possible areas for settlement such as the Cape Verde islands. For example, Knox's involvement in bio-prospecting based on the Relation is recognizable only if his unpublished second edition and journal of his voyage to Tonqueen are also consulted. Similarly, it is necessary to trace the movement of ideas from the Relation to the company's correspondence to see the contribution of the work to attempts at the transplantation of crops, agricultural techniques and human experts around the globe. Many merchants like Knox moved across areas that are now often studied separately, such as the Indian and Atlantic Oceans, taking their ideas and prejudices as well as their papers and specimens with them. They also occupied roles such as author and slave trader that are often studied within quite different conceptual frameworks. Following their journeys across these spaces can contribute to a greater awareness of how ideas and techniques were transferred between different areas of the world in the early modern period. 